\title{
Evaluation of Swietenia mahagoni Jacq seed extracts in promoting wound healing properties
}

\author{
Hartati a, b, ${ }^{*}$, Hasmida Mohd-Nasir ${ }^{b}$, Liza Md Salleh b, c, Irma Suryani Idris a, Azila Abd Aziz ${ }^{c}$ \\ a Biology Department, Universitas Negeri Makassar, South Sulawesi, Indonesia \\ b Centre of Lipids Engineering \& Applied Research (CLEAR), Ibnu Sina Institute for Scientific \& Industrial Research, Universiti Teknologi Malaysia, \\ 81310 UTM Johor Bahru, Johor, Malaysia \\ c Bioprocess and Polymer Engineering Department, Faculty of Chemical \& Energy Engineering, Universiti Teknologi Malaysia, 81310 UTM Johor \\ Bahru, Johor, Malaysia
}

*Corresponding author: hartati@unm.ac.id

\section{Article history}

Received 28 March 2018

Revised 1 April 2018

Accepted 20 May 2018

Published Online 3 December 2018

\begin{abstract}
Swietenia mahagoni or known as tunjuk langit is a widely known plant to possess good properties in treating diseases as well as a wound treatment. The purpose of this work was to examine the wound healing ability of the seed extracts in term of its ability to promote cell proliferation and migration. The extracts from two extraction methods, i.e. supercritical carbon dioxide and Soxhlet, were evaluate using cytotoxicity and scratch assays on human skin fibroblast cells. The findings showed that the extraction yield using supercritical fluid extraction was lower than Soxhlet method with $48.9 \%$ yield recovery. In addition, the seed extracts were able to stimulate cell growth and migratory effect. This information can be used as a basis to performed subsequent study to report wound healing activity of this plant material.
\end{abstract}

Keywords: Swietenia mahagoni, cell proliferation, cell migration, extraction methods, wound healing

\section{INTRODUCTION}

Wound healing is a process involving inflammation as well as the formation and remodeling of new tissue (Guartner et al., 2008; Fronza et al., 2009). The first phase is re-epithelization, where the processes such as migration of keratinocytes of the injured epidermis and hair follicles followed by proliferation of these cells at the wound edge, are observed at the beginning of new tissue formation. Keratinocytes redifferentiation is then occurred to restore the barrier function. Additionally, fibroblast is important in the repair of the injured dermis. These cells proliferation are expanding and migrate into the wound area, synthesize new extracellular matrix (ECM), as well as express thick actin bundles as myofibroblasts (Schafer and Werner, 2007; Guartner et al., 2008; Fronza et al., 2009).

The use of plants and preparations thereof to accelerate the wound healing process was reported years ago (Reuters et al., 2009; Schmidt et al., 2009). Their use is often based on traditional, without any scientific evidence of efficacy and little knowledge about putative active compounds or their mode of actions. As wound healing is a complex biological process, several in vitro and in vivo assays are presented. Among these, Liang et al. (2007) stated that the scratch assay has been proven as a valuable and inexpensive tool to obtain first insights into how plant preparations or their isolated compounds can positively influence the formation of new tissue.

When wounded or scratched, cell monolayers respond to the disruption of cell-cell contacts by increasing the concentration of growth factors and cytokines at the wound edge, thus initiating proliferation and migration of the cell. When performing a scratch assay, an artificial gap, a so-called "scratch" is created in a cell monolayer with a sharp object such as a syringe needle or pipette tip. The assay is performed on individual coverslips or in a multi-well plate.
The monolayers recovery and wound healing occur in a process that can be monitored over time. The wound heals in a patterned fashioncells polarize toward the wound, initiate protrusion, migrate, and close the wound. The progress of these events can be observed by manually imaging samples fixed at different time points, or by time-lapse microscopy (Liang et al., 2007; Fronza et al., 2009).

Swietenia mahagoni (Linn.) Jacq. is a plant mainly grows in tropical areas of Asia, for example, Malaysia, India, Indonesia and southern mainland China. The seeds have been used as folk medicine for hypertension, diabetes, and malaria treatments, while the decoction of its bark has been applied as a febrifuge (Chen et al., 2007). The therapeutic effects associated with the seeds are mainly caused by the biologically active ingredients, fatty acids and etranortriterpenoids (Bacsal et al., 1997). There are reports of S. mahagoni seeds having anti-inflammatory, antimutagenicity, and antitumour activities (Guevara et al., 1996). The plant extracts have been accounted to possess antibacterial and antifungal activities. Limonoid obtained from S. mahagoni has antifungal activity and diabetes therapy (Ardahe et al., 2010). The seeds of S. mahagoni are good agricultural product and have been found potentially rich in fat (64.9\%) (Ali et al., 2011).

The extraction methods are also playing an important role in evaluating the effectiveness of the plant extract. The traditional procedures for plant extractions include hydrodistillation and organic solvent extraction (percolation, maceration or Soxhlet methods). However, there are drawbacks with these methods such as time and labour consuming operation, and involves large volumes of hazardous solvents. Nevertheless, increasing solvent acquisition and disposal costs; and regulatory restrictions have triggered the interest in alternative extraction methods with less organic solvent consumption (Yamini et al., 2008). Therefore, it is highly desired to develop alternative extraction procedures with better efficiency and selectivity. 
Consequently, supercritical fluid extraction (SFE) is extensively studied for separation of active compounds from herbs and other plants as it is environmentally responsible and efficient extraction technique for solid materials. Lang and Wai (2001) have reviewed several advantages of SFE which are: (1) Shorter extraction time when using supercritical fluids, since they have relatively higher diffusivity and lower viscosity, (2) Continuous fluid flowing though samples could provide quantitative or complete extraction, (3) SFE is usually performed at low temperature, (4) The solvent power can be adjusted by varying the pressure and temperature, (5) Separation of solutes dissolved in supercritical fluid can be easily done by depressurization, (6) Only a little quantity of sample is needed, (7) Zero or little amount of organic solvent is needed, which is environmentally responsible. In addition, SFE provides more quality extract compare to conventional extraction methods as discussed by Hasmida et al. (2015).

The objective of the present study was to evaluate the ability of Swietenia mahagoni seed extracts to promote cells proliferation into and migration to the wounded monolayer which provide a basis on wound healing properties of the plant material. Human skin fibroblasts (HSF1184) were used, and platelet derived growth factor (PDGF) served as positive control. Two extraction methods were applied in order to compare the effectiveness of wound closure rate of the extracts which were supercritical carbon dioxide $\left(\mathrm{SC}-\mathrm{CO}_{2}\right)$ and Soxhlet extraction with hexane as solvent.

\section{EXPERIMENTAL}

\section{Plant material preparation}

S. mahagoni seeds were collected from Indonesia. The seeds were rinsed with tap water to remove any foreign particles and dirt prior to drying. Then, the cleaned seeds were cut into small pieces and dried in an oven at temperature of $50^{\circ} \mathrm{C}$ for one week to remove its moisture. The seeds were ground by a blender (Panasonic) with average particle sizes varied from 0.25 to $0.75 \mathrm{~mm}$.

\section{Chemicals}

\section{Supercritical carbon dioxide $\left(\mathrm{SC}-\mathrm{CO}_{2}\right)$ extraction}

The $\mathrm{SC}-\mathrm{CO}_{2}$ extraction equipment used in this study was similar to those of Mohd Nasir et al. (2017). The ground sample of $5 \mathrm{~g}$ was placed into an extractor vessel. The extracts were collected into a glass vial placed in the separator at ambient temperature and pressure. A flow rate of $\mathrm{CO} 2$ was $2 \mathrm{~mL} / \mathrm{min}$. The investigated values of pressure, temperature, and particle size were varied from 20 to $30 \mathrm{MPa}, 40$ to $60^{\circ} \mathrm{C}$, and 0.25 to $0.75 \mathrm{~mm}$, respectively. After each extraction, the obtained extract was placed into glass vials, sealed and stored at $4{ }^{\circ} \mathrm{C}$ to prevent any possible degradation.

\section{Soxhlet extraction}

The extraction of Swietenia mahagoni seed was carried out as described by Markom et al. (2007) with slight modifications. The extraction of Swietenia mahagoni was implemented by using Soxhlet extraction technique. To prepare the extract, $5 \mathrm{~g}$ of powdered $S$. mahagoni seed were weight and placed in a Whatmann $25 \mathrm{~mm} \times 100$ $\mathrm{mm}$ cellulose thimble while $150 \mathrm{~mL}$ of hexane $(100 \%)$ were placed at the bottom of the apparatus. The extraction process was done for 6 hours at temperature $65^{\circ} \mathrm{C}$. Then, the extraction yield was put in the rotary evaporator (BUCHI rotavapor, R-114) at $40^{\circ} \mathrm{C}$ for 2 hours to remove the solvent. The extracts were then placed in room temperature condition before weighing gravimetrically to calculate the yields. The samples were stored at $4^{\circ} \mathrm{C}$ in refrigerator for further analysis.

\section{Expression of yield}

The extraction yield was calculated using the following equation where $m_{0}$ and $m_{1}$ were mass of sample and extract in grams $(\mathrm{g})$, respectively.

$$
\text { Percentage of extraction yield }(\%)=\frac{m_{1}}{m_{0}} \times 100
$$

\section{Cell proliferation assay}

The method described by Ranzato et al. (2011) was used. The proliferation activity of human skin fibroblast (HSF1184) cells after treated with crude extracts was determined by methylthiazol tetrazolium (MTT) colorimetric assay. All cells were cultured in minimum essential medium (MEM) $+10 \%$ fetal bovine serum (FBS) + $1 \%$ pen Strype (PS) under $5 \% \mathrm{CO}_{2}$ humidified incubator. The cells were seeded at a density of $2 \times 10^{5}$ cells/well in 96-well plate and incubated for $24 \mathrm{hr}$ prior to treatment. The test samples were prepared by dissolving $S$. mahagoni extract in MEM to yield the final concentration of $10,1,0.1,0.01,0.001$ and $0.0001 \mathrm{mg} / \mathrm{mL}$. The medium was replaced after 24 hours with $200 \mu \mathrm{L}$ of MEM containing $10 \%$ FBS and 1\% PS; and serial dilution of plant extracts. After incubation, the cells were washed with phosphate buffered saline (PBS), $20 \mu \mathrm{L}$ freshly prepared MTT solution $(5 \mathrm{mg} / \mathrm{mL})$ was added into each well and cells were incubated at $37^{\circ} \mathrm{C}$ for 5 hours. The MTT solution was then removed and replaced with $200 \mu \mathrm{L}$ DMSO to allow dissolution of the purple MTT formazan crystal. The absorbance was measured at $540 \mathrm{~nm}$ using ELISA plate reader.

\section{Cell migration assay}

The wound closure of the HSF1184 was evaluated using scratch wound assay which measures the expansion of a cell population on surfaces modified from Fronza et al. (2009). The cells were cultured into 12 -well plate at a concentration of $3 \times 10^{5}$ cells until confluent. Then, a linear wound was made on the monolayer with a sterile $200 \mu \mathrm{L}$ pipette tip. Any cellular debris was removed by washing the cells with PBS. MEM (control), platelet derived growth factor (positive control), the crude extracts $(0.01 \mathrm{mg} / \mathrm{mL})$ was added to the cells and incubated for 24 hours at $37^{\circ} \mathrm{C}$. Two representatives images from each well of the scratched areas under each condition were photographed at 0,12 and 24 hours to measure the wound closure. The data were analysed with NIH ImageJ software (Ranzato et al., 2011). Wound closure was determined by the difference in wound width between 0 hour and 24 hours.

\section{Statistical analysis}

Data were expressed as the mean \pm S.E.M. Results were submitted to the one-way analysis of variance ANOVA, followed by the post hoc Tukey's test, using the SPSS 16.0 software. Values of $p<0.05$ were considered statistically significant.

\section{RESULTS AND DISCUSSION}

\section{Extracted oil yield of $S$. mahagoni seeds}

The extraction of $S$. mahagoni seeds was done using two different extraction methods which were supercritical carbon dioxide $\left(\mathrm{SC}-\mathrm{CO}_{2}\right)$ and Soxhlet extraction. The comparison of both extraction methods was shown in Fig. 1. Generally, the figure shows that Soxhlet extraction gave the highest percentage oil yield $(41.08 \% \pm 0.98)$ compared to SC$\mathrm{CO}_{2}$ extraction which was $20.07 \% \pm 0.48$. However, taking into account the extraction time, $\mathrm{SC}-\mathrm{CO}_{2}$ offer better extraction process since Soxhlet extraction required 6 hours of extraction time while SC$\mathrm{CO}_{2}$ extraction process only takes 3 hours to obtain the highest extracted oil yield.

The higher oil yield obtained using Soxhlet extraction compared to the $\mathrm{SC}-\mathrm{CO}_{2}$ extraction method is due to the high temperature and long extraction time applied during the extraction procedure. High temperatures can increase the volatility of the solute hence enhancing the solute solubility in hexane. Besides, longer extraction time increase the contact time between the solute and solvent molecules resulting in high extracted oil yield. The drawback of this properties is that the method will extract all of the solutes, including impurities within the particle. On the other hand, $\mathrm{SC}-\mathrm{CO}_{2}$ extraction technique offers better selectivity ability and it was proven by only $48.9 \%$ yield recovery compared to Soxhlet method. 


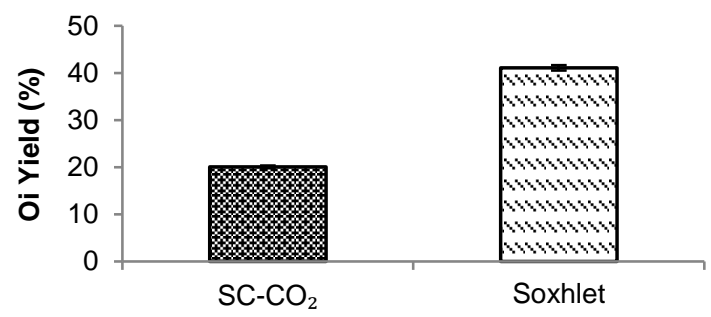

Extraction Methods

Fig. 1 Percentage of S. mahagoni seed oil extract using $\mathrm{SC}-\mathrm{CO}_{2}$ and Soxhlet extraction

The comparison between these two extraction methods had been done previously as the researchers proved the effectiveness of $\mathrm{SC}-\mathrm{CO}_{2}$ extraction to obtain more pure substances. For example, Zhao and Zhang (2014) stated that the Soxhlet had the highest yield, followed by SFE and hydrosilation. They explained that the nature of Soxhlet in which it extracts high molecular weight molecule is one of the reasons for the obtained result. A similar result also published by Liza et al. (2012) where the flavonoid content was detected in significant quantity when extracted using $\mathrm{SC}-\mathrm{CO}_{2}$ method.

\section{Cell proliferation analysis of $\boldsymbol{S}$. mahagoni seed extracts}

Cytotoxicity test using (3-(4,5-dimethyl-tiazol-2y) 2,5-diphenyltetrazolium bromide (MTT) assay was done to obtain the suitable extracts concentration which gives non-toxic effect towards cell proliferation. MTT assay is useful in vitro model for testing cytotoxicity because it can show the ability of the compound to stimulate the proliferation of the fibroblast. The toxic compounds will affect the basic functions of the cells and the toxicity can be determined by assessing cellular damage. MTT will enter the cell and passes the mitochondria and the ring of MTT will be reduced to a dark purple formazan product which is insoluble in the aqueous solution. The reduction of the MTT can only be implemented by the metabolically active cells, and therefore this reduction can directly measure the viability of the cell. In other words, this screening can assist for the identification of the suitable amount of extracts that can be utilized for next cell culture study.

Fig. 2 shows the relative viability of fibroblast cells after being treated with $S$. mahagoni extracts for 24 hours at different concentrations ranging from 0.0001 to $10 \mathrm{mg} / \mathrm{mL}$ for both extraction methods. Generally, all extracts showed the same pattern of relative viability at $0.1,0.01$ and $0.001 \mathrm{mg} / \mathrm{mL}$ extracts' concentrations. The highest relative cell viability was indicated by linoleic acid (LA), which was the standard chemical marker in this study, at $0.1,0.01$ and 0.001 $\mathrm{mg} / \mathrm{mL}$ with $145 \% \pm 0.015,190 \% \pm 0.037$ and $165 \% \pm 0.037$, respectively, provide an idea that the high quality compound without impurities shows a favourable response to cell proliferation rate. Meanwhile, the $\mathrm{SC}-\mathrm{CO}_{2}$ and Soxhlet extracts showed only a slight difference in cell proliferation between each other at concentrations of $0.1,0.01$ and $0.001 \mathrm{mg} / \mathrm{mL}$. However, the extracts obtained from Soxhlet extraction demonstrates relatively low cell viability compared to others suggesting that the $\mathrm{SC}-\mathrm{CO}_{2}$ extraction from $\mathrm{S}$. mahagoni seeds results in a better effect on the rate of cell proliferation.

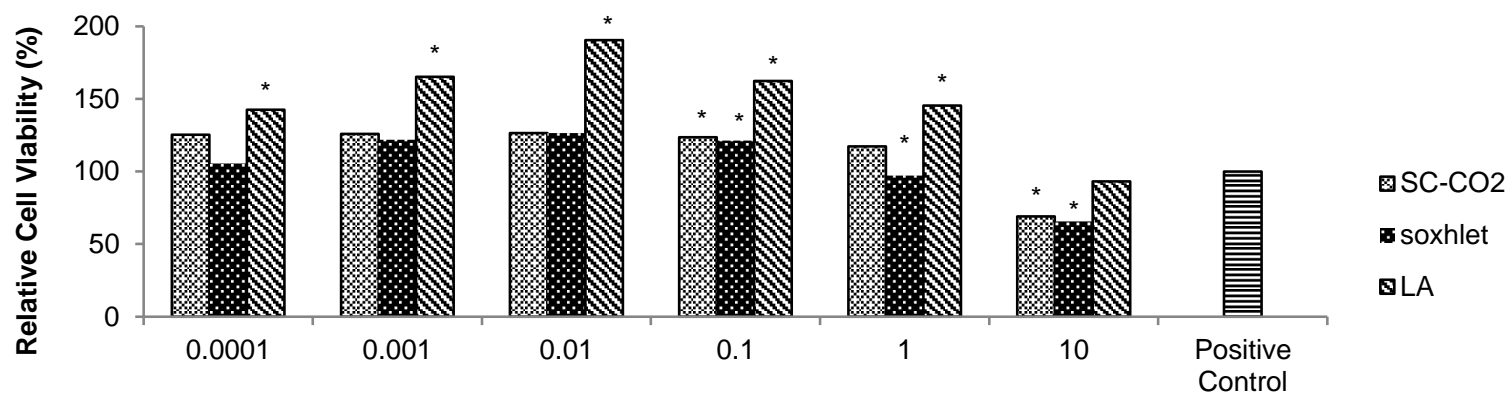

Concentrations of S. mahagoni seed extracts $(\mathrm{mg} / \mathrm{mL})$

Figure 2 Effect of S. mahagoni extracts using SC- $\mathrm{CO}_{2}$ and Soxhlet extraction on human skin fibroblast (HSF1184) cells evaluated for 24 hours.

Referring to Ranzato et al. (2009) and Wang et al. (2011), relative cell viability higher than control is considered to have a growth promoting activity, while lower values than control show a toxic effect. Based on the data obtained from this analysis, it can be concluded that all extract's concentrations ranging from 0.1 to $0.001 \mathrm{mg} / \mathrm{mL}$ did not show any toxicity effects on HSF1184, even promoting fibroblast proliferation as the cell's survival rate was higher than the control. The concentrations dose higher than that is not suitable to be applied might be due to its high antioxidant properties which will provide harmful effect towards the fibroblast cells (Mbata, 2014). Previously, Ghosh et al. (2009) found that two doses of methanolic extract of S. mahagoni seeds $(50$ and $100 \mathrm{mg} / \mathrm{kg}$ ) did not show any significant toxic effect up to $1.2 \mathrm{~g} / \mathrm{kg}$ of rat weight within 24 hours. According to other studies conducted using brine shrimp lethality assay, $\mathrm{LD}_{50}$ oral acute toxicity for $S$. mahagoni methanolic extracts exceed $2,500 \mathrm{mg} / \mathrm{kg}$ suggests that the extract of this plant was relatively nontoxic. The results of the study coincide with the fact that this plant can be used as traditional medicine (Sahgal et al., 2010).

Although in vitro cytotoxicity studies conducted on monolayer culture (fibroblasts) cannot be directly linked to in vivo assays, this finding provides an important basis for subsequent studies on specific bioactive compounds and mechanisms that act as proliferation agent. Besides, the data of this study can be used as a quick assessment of the cytotoxic effects of $S$. mahagoni seed extract on fibroblast cells.
Therefore, based on these result (Figure 2), the concentration of 0.1, 0.01 , and $0.001 \mathrm{mg} / \mathrm{mL}$ were selected as the appropriate concentrations to be applied in the next assay which was scratch assay to evaluate the ability of the extracts in promoting cell migration.

\section{Cell migration analysis of $S$. mahagoni seed extracts}

Scratch assay have been previously used to study the characteristics of proliferation and migration of various cell types after being treated with extracts from different species such as Astragalus, Calendula, Hemigraphic, Matricaria and Simmondsia (Fronza et al., 2009; Edwin and Nair, 2011 ; Ranzato et al., 2011; Sevimli-Gur et al., 2011). The reported optimum incubation period after the sctraching and cell treatment for both fibroblasts and keratinocytes with plant extracts is 12-72 hours, depending on the type of cells, extracts and scratches. The application of plant extracts with an optimum concentration of specific compounds can reduce or decrease the rates of cell proliferation and migration. High extract concentrations of legume genus Astragalus (10 $\mathrm{mg} / \mathrm{mL}$ ) and jojoba (Simmondsia chinensis) seed (wax, 5\% v/v) are less favorable for proliferation and migration of cells than less concentrated extracts $(1 \mathrm{mg} / \mathrm{mL} ; 1 \%$, v/v) (Ranzato et al., 2011; Sevimli-Gur et al., 2011). To confirm the healing properties of $S$. Mahagoni seed extracts discussed in the previous section, the ability of this extract to encourage fibroblast migration has been studied. 
In this study, migration of fibroblast cells was studied after 24 hours of wounded cells and treated with two different $S$. mahagoni extracts. Fig. 3 shows the effects of different $S$. mahagoni samples based on the methods and concentration of extracts towards fibroblast cells. The chart illustrates that $\mathrm{SC}-\mathrm{CO}_{2}$ extract at concentration of $0.001 \mathrm{mg} / \mathrm{mL}$ and Soxhlet extract at 0.1 and $0.01 \mathrm{mg} / \mathrm{mL}$ showed significant effect on cell migration compared to negative control (MEM + 10\% FBS +
$1 \%$ antibiotic mixture) $(p<0.05)$, with the values of $85.306 \% \pm 0.966$, $93.496 \% \pm 3.314$, and $83.904 \% \pm 2.901$, respectively, and not statistically different compared to LA and PDGF-BB (positive control). However, there is no significant difference noticed on the trend of wound closure percentage when treated with S. mahagoni extracts from both extraction methods, applying that the extracts of both methods can promote cell migration.

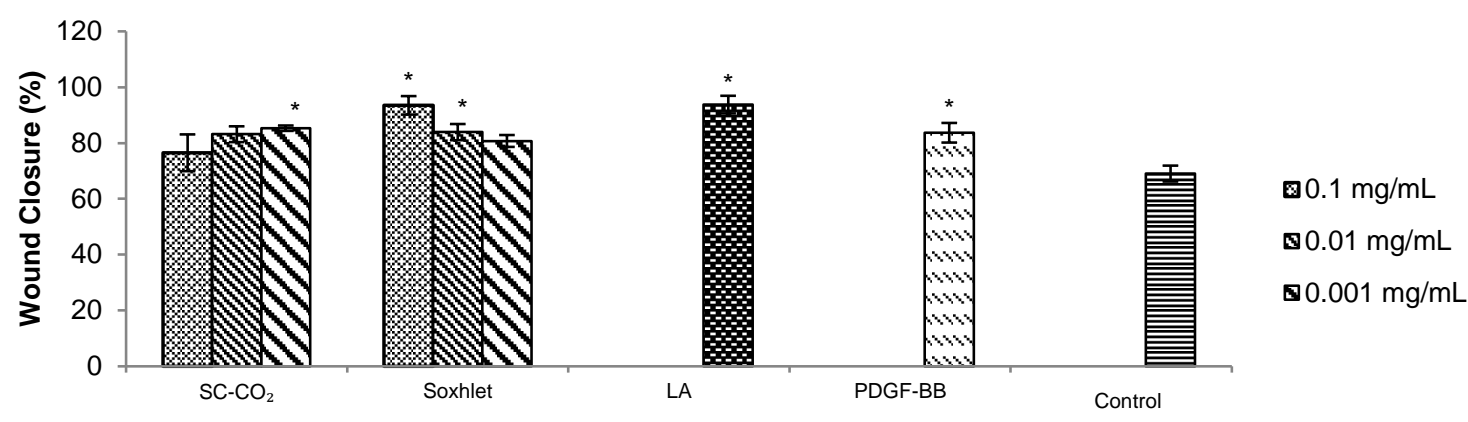

S. mahagoni seed extracts

Fig. 3 Cell migration after wounded and treatment using different S. mahagoni seed extracts at concentration $0.1,0.01$ and $0.001 \mathrm{mg} / \mathrm{mL}$, standard marker, positive and negative controls for 24 hours.

The extracts from $S$. mahagoni seed, LA and PDGF repaired the cells to the $>90 \%$ confluent level within 24 hours, in contrast with negative control (Fig. 4).

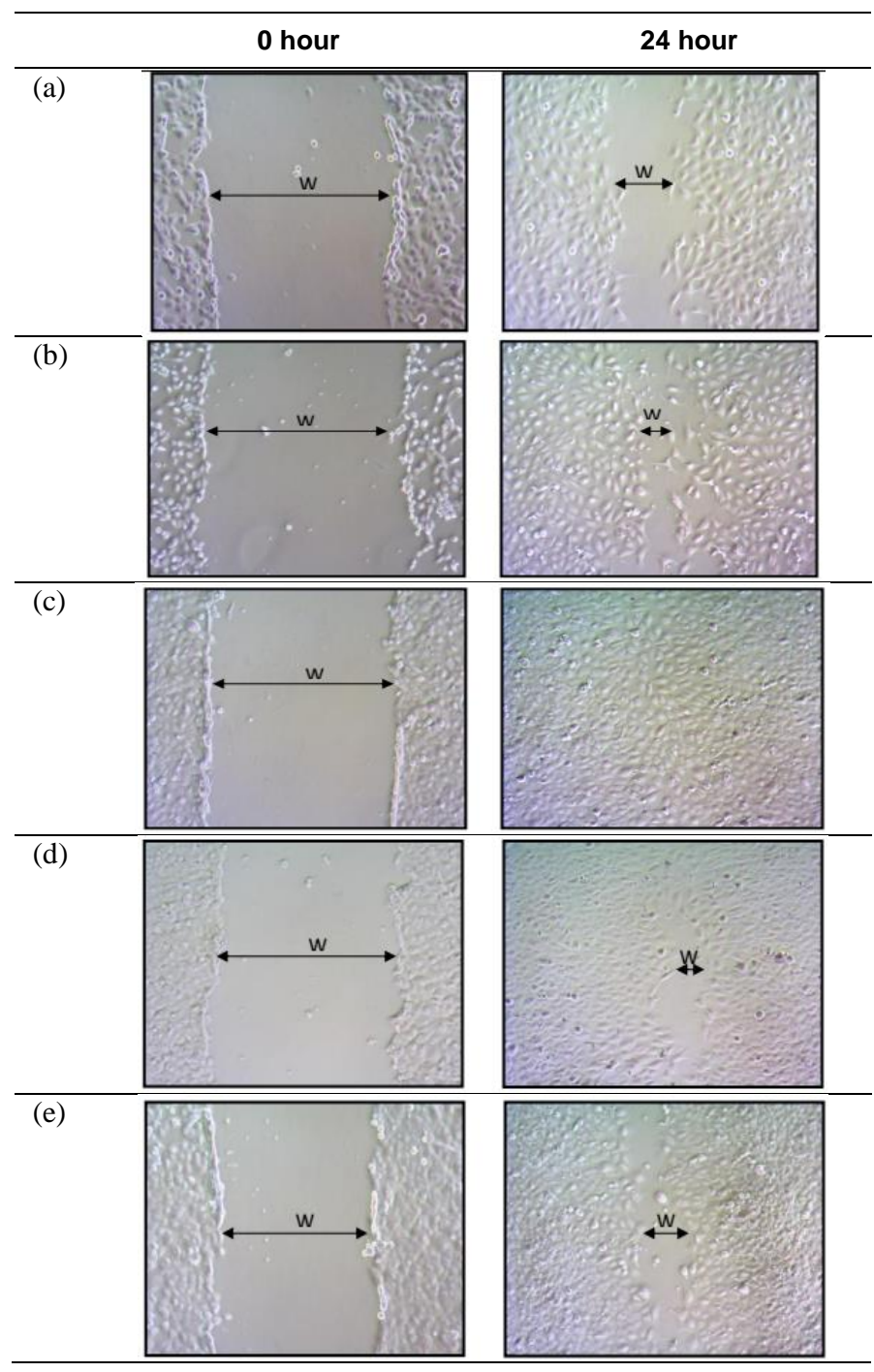

Fig. 4 Cell migration of (a) negative control, (b) positive control, (c) Linoleic acid (LA), (d) SC-CO $\mathrm{CO}_{2}$ extract of S. mahagoni, (e) Soxhlet extract of $S$. mahagoni at 0 and 24 hours.
The extract at a concentration of $0.1 \mathrm{mg} / \mathrm{mL}$ showed a higher percentage of wound closure than positive control ( $2 \mathrm{mg} / \mathrm{mL}$ of PDGF). This finding explains that $S$. mahagoni seed extracts can promote similar wound healing activity as PDGF at selected concentrations. The ability of the extracts in accelerating wound closure process might be due to the linoleic acid content which acts as an essential tissue remedy as it promotes chemotactic and angiogenesis by maintaining moisture in the environment and speeding up the tissue granulation process (Ferreira et al., 2012). Linoleic acid also plays an important role of chemotaxis for macrophages, and it is very crucial in the expression of components for the fibrinolysis system (controlling the production of collagenase). Ferreira et al. (2012) reported high concentrations of linoleic acid $(65 \%)$ was one of the factors that contribute to positive results in wound healing.

\section{CONCLUSION}

The ability of Swietenia mahagoni seed extracts in possessing wound healing properties was accessed in term of cell proliferation and migration using cytotoxicity and scratch assays, respectively. The findings suggest that all extracts can stimulate fibroblast growth in which could play a vital role in its effect on tissue repair. These assessments can be used as a basis to report wound healing activity of plant material and subsequent study should be made especially in vivo assay to determine the suitable dosage for human consumption.

\section{ACKNOWLEDGEMENT}

The authors gratefully acknowledge the financial support by the Ministry of Research and Higher Education Indonesia, and also to Universitas Negeri Makassar (UNM) and Universiti Teknologi Malaysia (UTM) for the use of laboratory instruments. Acknowledgement also extended to Research University Grants $12 \mathrm{H} 93$ and $06 \mathrm{H} 30$ for funding this study.

\section{REFERENCES}

Adetutu, A., Morgan, W.A., Corcoran, O. 2011. Ethnopharmacological survey and in vitro evaluation of wound-healing plants used in South-Western Nigeria. J. Ethnopharmacol. 137, 50-56.

Ali, M.A., Sayeed, M.A., Islam, M.S., Yeasmin, M.S., Khan, G.R.M.A.M., Ida, I.M. 2011. Physicochemical and antimicrobial properties of Trichosanthes anguina and Swietenia mahagoni seeds. Bull. Chem. Soc. Ethiop. 25(3), 427-436. 
Alrdahe, S.S., Abdulla, M.A., Razak, S.A., Kadir, F.A., Hassandarvish, P. 2010 Gastroprotective activity of Swietenia mahagoni seed extract on ethanolinduced gastric mucosal injury in rats. World Acad. Sci. Eng. Technol. 67, 883-887.

Balekar, N., Gangadhar, K.N., Nakpheng, T., Jehtae, K., Srichana, T. 2012. Evaluation of the wound healing potential of Wedelia trilobata $(\mathrm{L})$ leaves. J. Ethnopharmacol. 141, 817-824.

Barile, F.A., Dierick, P.J, Kristen, U. 1994. In vitro cytotoxicity testing for prediction of acute human toxicity. J. Cell Biol. Toxicol. 10, 155-162.

Bascal, K., Chavez, L., Diaz, I., Espina, S., Javillo, J., Manzanilla, H., Motalban, J., Panganiban, C., Rodriguez, A., Sumpaico, C., Talip, B., Yap, S. 1997. The effect of Swietenia mahagoni (mahogany) seed extract on indomethacin-induced gastric ulcers in female Sprague-Dawley rats. Acta Med. Philipp. 3, 127-139.

Casas, I., Mantell, C., Rodroguez, M., Torres, A., Macias, F.A., De la Ossa, E.J.M. 2008. Supercritical fluid extraction of bioactive compounds from sunflower leaves with carbon dioxide and water on a pilot plant scale. $J$. Supercrit. Fluids. 45, 37-42.

Chen, Y.Y., Wang, X.N., Fan, C.Q., Yin, S., Yue, J.M. 2007. Swiemahogins A and B, two novel limnoids from Swietenia mahogany. Tetrahedron Lett. 48, 7480-7484.

Ekpo, M., Mbagwu, H., Jackson, C., Eno, M. 2011. Antimicrobial and wound healing activities of Centrosema pubescens (Leguminosae). J. Phys. Chem. Solids. 1,1-6.

Fronza, M., Heinzmann, B., Hamburger, M., Laufer, S., Merfort, I. 2009. Determination of the wound healing effect of Calendula extract using the scratch assay with 3T3 fibroblasts. J. Ethnopharmacol. 126, 463-467.

Guevara, A.P., Apilado, A., Sakurai, H., Kozuka, M., Tokuda, H. 1996. Antiinflammatory, antimutagenic and antitumor promoting activities of mahogany seeds, Swietenia macrophylla (Meliaceae). Philipp. J. Sci. 125, 271-278.

Hasmida, M.N., Md. Salleh, L., Nur Syukriah, A.R., Harisun, Y., Che Yunus, M.A., Abdul Majid, F.A. 2015. Total phenolic content and antioxidant activity of Quercus infectoria galls using supercritical $\mathrm{CO}_{2}$ extraction technique and its comparison with Soxhlet extraction. Pertanika J. Sci. Technol. 23 (2), 287-295.

Joseph, B., Justin, R.S. 2011. A comparative study on various properties of five medicinally important plants. Int. J. Pharm. 7(2), 206-211.

Lang, Q.Y., Wai, C.M. 2001. Supercritical fluid extraction in herbal and natural product studies - a practical review. Talanta. 53, 771-782.

Liu, J., Han, B., Liu, G.Li., He, .J., Yang, G. 2001. Solubility of the non-ionic surfactant tetramethylene glycol n-laurel ether in supercritical $\mathrm{CO}_{2}$ with npentanol. Fluid Phase Equilib. 15, 247-254

Liza, M.S., Abdul Rahman, R., Mandana, B., Jinap, S., Rahmat, A., Zaidul, I.S.M., Hamid, A. 2012. Supercritical fluid extraction of bioactive flavonoid from Strobilanthes crispus (pecah kaca) and its comparison with solvent extraction. Int. Food Res.J. 19(2), 503-508.

Mbata, T. 2014. Antioxidant nutrients: beneficial or harmful. Internet Journal of Food Safety. V, 29-33.

Mohd Nasir, H., Md Salleh, L., Ismail, A.R., Machmudah, S. 2017. Solubility correlation of gall (Quercus infectoria) extract in supercritical $\mathrm{CO}_{2}$ using semi-empirical equations. Asia-Pac. J. Chem. Eng. 12(5), 790-797.

Nagalakshmi, M.A.H., Thangadurai, D., Rao, D.M., Pullailah, T. 2001. Phytochemical and antimicrobial study of Churasia tabularis leaves. Fitoterapia. 72, 62-64.

Ranzato, E., Martinotti, S., Burlando, B. 2011. Wound healing properties of jojoba liquid wax: an in vitro study. J. Ethnopharmacol. 134, 443-449.

Sahgal, G., Ramanathan, S., Sasidharan, S., Mordi, M.N., Ismail, S. Mansor, S.M. 2009. Phytochemical and antimicrobial activity of Swietenia mahagoni crude methanolic seed extract. Trop. Biomed. 26 (3), 274-279.

Wang, Z., Pan, Z., Ma, H., Atungulu, G. G. 2011. Extract of phenolics from pomegranate peels. The Open Food Science Journal. 5, 17-25.

Yamini, Y., Khajeh, M., Ghasemi, E., Mirza, M., Javidnia, K. 2008. Comparison of essential oil compositions of Salvia mirzayanii obtained by supercritical carbon dioxide extraction and hydrodistillation methods. Food Chem. 108, 341-346.

Zhao, S., Zhang, D. 2014. Supercritical $\mathrm{CO}_{2}$ extraction of Eucalyptus leaves oil and comparison with Soxhlet extraction and hydro-distillation methods. Sep. Purif. Technol. 133, 443-451. 